\title{
Immunostimulatory Activity of Protein Hydrolysate from Oviductus Ranae on Macrophage In Vitro
}

\author{
Di Huang, ${ }^{1,2}$ Lubing Yang, ${ }^{1,2}$ Chenlu Wang, ${ }^{1}$ Sihui Ma, ${ }^{1,2}$ Li Cui, ${ }^{1,2}$ Shiyang Huang, \\ Xia Sheng, ${ }^{1}$ Qiang Weng, ${ }^{1,2}$ and Meiyu $\mathrm{Xu}^{1,2}$ \\ ${ }^{1}$ College of Biological Science and Technology, Beijing Forestry University, Beijing 100083, China \\ ${ }^{2}$ Beijing Key Laboratory of Forest Food Processing and Safety, Beijing Forestry University, Beijing 100083, China \\ Correspondence should be addressed to Meiyu Xu; xumeiyu@bjfu.edu.cn
}

Received 13 May 2014; Revised 24 November 2014; Accepted 27 November 2014; Published 22 December 2014

Academic Editor: Francesca Borrelli

Copyright (C) 2014 Di Huang et al. This is an open access article distributed under the Creative Commons Attribution License, which permits unrestricted use, distribution, and reproduction in any medium, provided the original work is properly cited.

Oviductus Ranae is the dry oviduct of Rana chensinensis, which is also called $R$. chensinensis oil. Oviductus Ranae is a valuable Chinese crude drug and is recorded in the Pharmacopoeia of the People's Republic of China. The aim of this study was to investigate the immunostimulatory activity of protein hydrolysate of Oviductus Ranae (ORPH) and to assess its possible mechanism. Immunomodulatory activity of ORPH was examined in murine macrophage RAW 264.7 cells. The effect of ORPH on the phagocytic activity of macrophages was determined by the neutral red uptake assay. After treatment with ORPH, NO production levels in the culture supernatant were investigated by Griess assay. The mRNA and protein expressions of inducible nitric oxide synthase (iNOS) were detected by RT-PCR and Western blotting. The production of TNF- $\alpha$, IL-1 $\beta$, and IL- 6 after treatment with ORPH was measured using ELISA assay. In addition, NF- $\kappa \mathrm{B}$ levels were also investigated by Western blot. The results showed that ORPH enhanced the phagocytosis of macrophage, increased productions of TNF- $\alpha$, IL-1 $\beta$, IL-6, and NO in RAW 264.7 cells, and upregulated the mRNA and protein expression of iNOS. Besides, NF- $\kappa$ B, levels in RAW 264.7 cells were elevated after ORPH treatment. These findings suggested that ORPH might stimulate macrophage activities by activating the NF- $\kappa \mathrm{B}$ pathway.

\section{Introduction}

Macrophages are a type of differentiated tissue cells that originate as blood monocytes. The cells have several functions such as the removal of cell debris, the killing of pathogenic microorganisms, and the processing and presentation of antigens to lymphocytes $[1,2]$. Macrophages are the first cells to recognize invading foreign bodies and are central to cell mediated and humoral immunity. Therefore, the activation of macrophages is a key event for effective innate and adaptive immunity. It is reported that activated macrophages can defend against pathogen invasion by secreting proinflammatory cytokines and releasing some inflammatory molecules such as tumor necrosis factor- (TNF-) $\alpha$, interleukin- (IL-) $1 \beta$, interleukin- (IL-) 6, or nitric oxide (NO) [3]. NO, as a freeradical gas, is synthesized by inducible nitric oxide synthase (iNOS) and mediates diverse functions, including vasodilatation, neurotransmission, immunoresponses, and inhibition of platelet aggregation and of extracellular matrix production $[4,5]$. NO has been identified as the major effector molecule involved in the destruction of tumor cells by activated macrophages [6]. Moreover, the involvement of NO during nonspecific host defense, macrophage-mediated killing, and the inhibition of the proliferation of microorganisms and tumor cells both in vitro and in vivo has previously been demonstrated [7].

Nuclear factor $\kappa \mathrm{B}(\mathrm{NF}-\kappa \mathrm{B})$ is a transcriptional factor that regulates a battery of genes that are critical to innate and adaptive immunity, cell proliferation, inflammation, and tumor development. In macrophages, NF- $\kappa \mathrm{B}$, in cooperation with other transcription factors, coordinates the expression of the genes encoding TNF- $\alpha$, IL- $1 \beta$, IL- 6 , and IL-8 [8]. Moreover, NF- $\kappa$ B plays a critical role in the activation of immune cells by upregulating the expression of many cytokines essential for the immune response [9]. NF- $\kappa \mathrm{B}$ activation also results in the upregulation of antiapoptotic genes thereby 
providing cell survival mechanism to withstand the physiological stress that triggered the inflammatory response. Enhanced NF- $\kappa \mathrm{B}$ activity can be directly induced by mutations of NF- $\kappa$ B genes and/or oncogenes that activate the NF$\kappa \mathrm{B}$ signaling pathway.

The Chinese brown frog (Rana chensinensis) is a special amphibian in northeastern China and has been used widely in Traditional Chinese Medicine [10]. However, one specific physiological phenomenon of $R$. chensinensis is that its oviduct expands prior to hibernation, instead of during the breeding period [11]. Moreover, the dessicated product of expanded oviduct of the female $R$. chensinensis, Oviductus Ranae, is a valuable Chinese crude drug and is recorded in the Pharmacopoeia of the People's Republic of China [12]. Oviductus Ranae is one of the best-known and highly valued oriental foods and medicines. Previous studies have shown that Oviductus Ranae is mainly composed of proteins, the content of which are up to $50 \%$ or more [13]. Traditional Chinese Medicine holds that Oviductus Ranae can nourish yin, moisten lung, and replenish the kidney essence. Meanwhile, activities of Oviductus Ranae such as antiaging, antilipemic, antioxidation, and antifatigue have also been demonstrated by modern pharmacological studies [14]. Although Oviductus Ranae was reported to augment the immune response by modulating macrophage function [15], the precise mechanism of its augmentation of cell-mediated immunity remains to be elucidated. In this study, we for the first time set out to explore the effect of protein hydrolysate of Oviductus Ranae on macrophage function, which could be one of major mechanism underlying Oviductus Ranae's immunomodulatory effect. Our results strongly indicate that protein hydrolysate of Oviductus Ranae enhances some of the key macrophage physiological parameters in vitro, including phagocytosis, NO secretion, and production of TNF- $\alpha$, IL-1 $\beta$, and IL-6.

\section{Materials and Methods}

2.1. Materials. Oviducts Ranae were collected from the adult female Chinese brown frogs (obtained during the prehibernation from Jilin Baekdu Mountain Chinese Brown Frog Breeding Farm, Jilin Province, China). All the procedures on animals were carried out in accordance with the Policy on the Care and Use of Animals by the Ethical Committee, Beijing Forestry University. Murine macrophage cell line RAW 264.7 (ATCC number TIB-71) and cell culture materials were purchased from the Cell Culture Centre of the Institute of Basic Medical Sciences, Chinese Academy of Medical Sciences, Beijing, China. Papain, trypsin, pepsin, neutral protease, and alkaline protease were purchased from Sigma. Griess reagent and nuclear (or cytoplasmic) protein extraction kit were obtained from Beyotime Biotechnology, China. Antibody against iNOS was from Santa Cruz Biotechnology Inc. (Dallas, TEX, USA). ELISA kits (for TNF- $\alpha$, IL- $1 \beta$, and IL-6) were purchased from Cusabio Biotech, China. Anti-NF$\kappa \mathrm{Bp} 65$ and anti-I $\kappa \mathrm{B}-\alpha$ were obtained from Biosynthesis Biotechnology, China.

2.2. Oviductus Ranae Protein and Protein Hydrolysate Preparation. Frozen Oviductus Ranae was thawed, chopped, and
TABLE 1: Conditions of enzymatic hydrolysis.

\begin{tabular}{lcc}
\hline Enzyme & $\mathrm{pH}$ & Temperature $\left({ }^{\circ} \mathrm{C}\right)$ \\
\hline Papain & 7.0 & 60 \\
Trypsin & 8.0 & 40 \\
Neutral protease & 7.5 & 55 \\
Pepsin & 2.5 & 37 \\
Alkaline protease & 9.0 & 50 \\
\hline
\end{tabular}

immediately mixed with phosphate buffered saline (PBS, $0.1 \mathrm{M} \mathrm{pH} \mathrm{7.4)}$ at 1:10 Oviductus Ranae to buffer ratio by continuous stirring combined with ultrasonic treatment for $2 \mathrm{~h}$. The mixture was centrifuged and the supernatant was collected. Protein was extracted from the supernatant by ammonium sulfate precipitation technique. Oviductus Ranae protein isolate was dispersed in distilled water obtain $6.0 \%(\mathrm{w} / \mathrm{v})$ protein slurry. Various enzymes (papain, trypsin, neutral protease, pepsin, and alkaline protease) were added to the protein solution, respectively, at varying temperature and $\mathrm{pH}$ as shown in Table 1 . The temperature and $\mathrm{pH}$ of the slurry were maintained constant for $3 \mathrm{~h}$, after which the hydrolysis was stopped by heating the slurry to $95^{\circ} \mathrm{C}$ and held for $10 \mathrm{~min}$. The hydrolysates were cooled to room temperature and centrifuged at 3,000 g for $10 \mathrm{~min}$. The clear supernatant was collected and freeze-dried and stored at $-20^{\circ} \mathrm{C}$ as protein hydrolysate of Oviductus Ranae.

2.3. Cell Culture. The RAW 264.7 mouse macrophage cell line was cultured in DMEM supplemented with $10 \%$ fetal bovine serum, $2 \mathrm{mM}$ L-glutamine, $100 \mathrm{U} / \mathrm{mL}$ penicillin, and $100 \mu \mathrm{g} / \mathrm{mL}$ streptomycin at $37^{\circ} \mathrm{C}$ in a $5 \%$ humidified incubator with $5 \% \mathrm{CO}_{2}$.

2.4. Cytotoxicity Assay on Macrophages. Cytotoxicity on RAW 264.7 cells was measured by conventional MTT assay. Cells were cultured in 96-well plates at a density of $3 \times$ $10^{4}$ cells $/ \mathrm{mL}$ with test substances for $48 \mathrm{~h}$ at $37^{\circ} \mathrm{C}$ and $5 \% \mathrm{CO}_{2}$. After incubation, $20 \mu \mathrm{L}$ of MTT (3-(4,5-dimethylthiazol-2yl)-2,5-diphenyltetrazolium bromide, $5 \mathrm{mg} / \mathrm{mL}$ ) reagent was added to each well and incubated for $4 \mathrm{~h}$ at $37^{\circ} \mathrm{C}$ in the dark. The culture medium containing the MTT solution was replaced by $200 \mu \mathrm{L}$ DMSO (dimethyl sulfoxide) and shaken in the dark for $15 \mathrm{~min}$ at room temperature for complete dissolution of the MTT formazan productions. The optical density of each well was measured by absorbance at $570 \mathrm{~nm}$ using a Benchmark Plus microplate reader (Bio-Rad).

\subsection{Neutral Red Uptake Assay for Macrophage Phagocytosis.} The phagocytic ability of macrophage was measured by neutral red uptake assay $[16,17]$. After cells were cultured with test substances for $48 \mathrm{~h}, 100 \mu \mathrm{L}$ neutral red solutions (dissolved in $10 \mathrm{mM}$ PBS with the concentration of $0.075 \%$ ) was added and incubated for $1 \mathrm{~h}$. The supernatant was discarded and the cells in 96-well plates were washed with PBS twice to remove the neutral red that was not phagocytized by RAW 264.7 cells. Then, cell lysate (ethanol and $0.01 \%$ acetic acid at the ratio of $1: 1,100 \mu \mathrm{L} /$ well) was added to lyse cells. After cells were 
incubated in room temperature overnight, the optical density at $540 \mathrm{~nm}$ was measured by a microplate reader.

2.6. Nitric Oxide (NO) Production by Macrophages. Measurement of nitrite in medium was used as an indicator of $\mathrm{NO}$ production $[9,16]$. RAW 264.7 cells $\left(5 \times 10^{5}\right.$ cells $\left./ \mathrm{mL}\right)$ were cultured in 96-well plates with test substances. After $24 \mathrm{~h}$, culture supernatants were collected and nitrite, the stable reaction product of $\mathrm{NO}$ with molecular oxygen, was measured using Griess reagent. Equal volumes of Griess reagent and sample were incubated together at room temperature for $10 \mathrm{~min}$. Nitrite production was determined by comparing the absorbance at $540 \mathrm{~nm}$ with a standard curve generated by $\mathrm{NaNO}_{2}$.

2.7. RT-PCR Analysis of iNOS $m R N A$. Total RNA from $2 \times$ $10^{6}$ cells was extracted with $1 \mathrm{~mL}$ Trizol reagent. The RNA precipitate was suspended in $10 \mu \mathrm{L}$ of DEPC-treated water. The reaction tubes for cDNA synthesis contained $2 \mu \mathrm{g}$ total RNA, $10 \mu \mathrm{M}$ oligo (dT) 18 primer, $2.5 \mathrm{mM}$ dNTPs, $25 \mathrm{U}$ RNase inhibitor, and $200 \mathrm{U}$ Moloney murine leukemia virus reverse transcriptase in total $25 \mu \mathrm{L}$ volume per tube with the reaction of: $5 \mathrm{~min}$ at $75^{\circ} \mathrm{C}, 1 \mathrm{~h}$ at $37^{\circ} \mathrm{C}$, and $5 \mathrm{~min}$ at $95^{\circ} \mathrm{C}$. The cDNA was stored at $-20^{\circ} \mathrm{C}$ before used. PCR amplification of cDNA encoding iNOS was carried out in $25 \mu \mathrm{L}$ reaction volume containing $1 \mu \mathrm{L}$ cDNA template, $2.5 \mu \mathrm{L}$ of $10 \mathrm{X}$ Taq DNA polymerase buffer, $1.5 \mu \mathrm{L} \mathrm{MgCl}_{2}(25 \mathrm{mM}), 0.5 \mu \mathrm{L} \mathrm{dNTP}$ mix $(10 \mathrm{mM}), 1 \mu \mathrm{L}$ each of primer $(10 \mu \mathrm{M})$, and $1 \mathrm{U}$ Taq DNA polymerase. The sense and antisense primers for iNOS were $5^{\prime}$-GTCTTGCAAGCTGATGGTCA- $3^{\prime}$ and $5^{\prime}$-GGCCTCAGCTTCTCATTC-TG- $3^{\prime}$, respectively. The expected product length is $602 \mathrm{bp}$. As for $\beta$-actin, the sense and antisense primers were $5^{\prime}$-AGGCATCCTGACCCTGAAGTAC$3^{\prime}$ and $5^{\prime}$-TTCATGAGGTAGTCTGTCAG- $3^{\prime}$, respectively. The length of expected product is $389 \mathrm{bp}$. The reaction mixture was denatured at $94^{\circ} \mathrm{C}$ for $5 \mathrm{~min}$ and subjected to 30 cycles of $30 \mathrm{~s}$ at $94^{\circ} \mathrm{C}, 50 \mathrm{~s}$ at $52^{\circ} \mathrm{C}, 50 \mathrm{~s}$ at $72^{\circ} \mathrm{C}$, and a final extension step of $10 \mathrm{~min}$ at $72^{\circ} \mathrm{C}$. The amplification was accomplished in 2720 Thermal Cycler (Gene Co. Ltd.). The PCR products were analyzed on a $2 \%$ agarose gel containing ethidium bromide. The bands of PCR products were visualized under UV light and analyzed with iPP 6.0. The results were expressed with the relative intensity compared with $\beta$ actin.

2.8. Western Blot. Proteins Expression of iNOS, NF- $\kappa \mathrm{B}$, and $\mathrm{I} \kappa \mathrm{B}-\alpha$ was measured by Western blot analysis. RAW 264.7 cells were cultured in 6-well plates with test substances for $24 \mathrm{~h}[9,18]$. Cells were collected by $0.02 \%$ EDTA kept on ice for $30 \mathrm{~min}$, before the nuclear proteins and cytoplasmic proteins were isolated, respectively, by using nuclear and cytoplasmic protein extraction kit. Protein was then resolved by $10 \%$ SDS-PAGE and transferred onto polyvinylidene difluoride membranes. After blocking, the membranes were incubated with the target antibody. The horseradish peroxidaseconjugated secondary antibody to IgG was used. $\beta$-actin was selected as the endogenous control.
2.9. Measurement of Cytokine Production. For cytokine immunoassays, RAW 264.7 cells were cultured for $24 \mathrm{~h}$ at a density of $3 \times 10^{5}$ cells $/ \mathrm{mL}$ in 96 -well plates. Supernatants were removed at the indicated time, and TNF- $\alpha$, IL- $1 \beta$, and IL- 6 production were quantified by sandwich immunoassays using the protocol supplied by ELISA kits.

2.10. Preparation of Peptide Fractions. To obtain peptide fractions with different molecular weights, the hydrolysates were subjected to ultrafiltration using 3,5 , and $10 \mathrm{kDa}$ molecular weight cut-off membranes. Three fractions, namely, $<3 \mathrm{kDa}$, $3 \mathrm{kDa}-5 \mathrm{kDa}$, and $5 \mathrm{kDa}-10 \mathrm{kDa}$, were obtained. All fractions were lyophilized for use in the experiments.

2.11. Statistical Analysis. The data were expressed as means \pm S.D. The significance of difference was evaluated with oneway ANOVA, followed by Student's $t$-test to statistically identify differences between the control and treated groups. Significant differences were set at $P<0.05$ and $P<0.01$.

\section{Results}

3.1. Effect of Protein Hydrolysate of Oviductus Ranae on Cell Viability. Various protein hydrolysates of Oviductus Ranae were prepared by papain, trypsin, pepsin, neutral protease, and alkaline protease (referred to as ORPH-pa, ORPH-tp, ORPH-pe, ORPH-np, and ORPH-ap, resp.). To make sure the measurement of phagocytosis and NO production can well represent the cell function without any changes in cell quantity, it was necessary to evaluate the cytotoxic effect of protein hydrolysates of Oviductus Ranae on RAW 264.7 cells before further tests were carried out. MTT assay indicated that the protein hydrolysates did not show cytotoxic effects on RAW 264.7 cells in concentration ranging from 0 to $500 \mu \mathrm{g} /$ $\mathrm{mL}$ (Figure 1). Thereafter, the cells were treated with the hydrolysates in $500 \mu \mathrm{g} / \mathrm{mL}$ concentration during subsequent experiments.

3.2. Effect of Protein Hydrolysate of Oviductus Ranae on Phagocytosis. To determine the effect of Oviductus Ranae protein and protein hydrolysates on the phagocytic activity of macrophage, the neutral red uptake assay was performed. After incubation in culture medium with or without test substances $(500 \mu \mathrm{g} / \mathrm{mL})$ for $48 \mathrm{~h}$, RAW 264.7 macrophages cells were used to test the phagocytosis. Interesting, compared with the control (without test substances), Oviductus Ranae protein and all hydrolysates enhanced the phagocytic activity of macrophage (Figure 2(a)). Among them, ORPH-np exhibited the most significant promoting activity (macrophage phagocytosis was increased by $109.1 \%$ compared with untreated group, $P<0.01$ ), which is as high as the LPS-treated positive control group (Figure 2(a)). To eliminate the effect of neutral protease on phagocytic activity of macrophage, the cells pretreated with the medium contained same levels of neutral protease with ORPH-np were as control, the effect of ORPH-np $(10-1000 \mu \mathrm{g} / \mathrm{mL})$ on phagocytic activity of macrophage was investigated. The result indicated that ORPH-np promoted the phagocytosis of macrophage, and the activity revealed in a dose-dependent manner in 


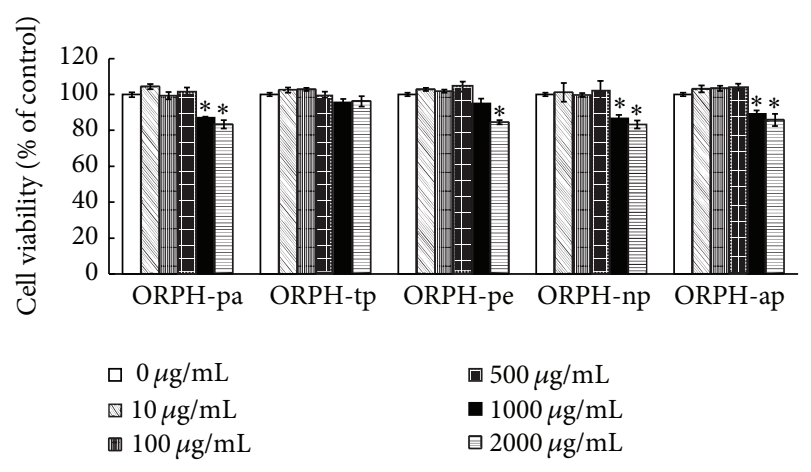

FIGURE 1: Effect of protein hydrolysate of Oviductus Ranae on cell viability. RAW 264.7 cells were pretreated with test substances $(0$, $10,100,500,1000$, and $2000 \mu \mathrm{g} / \mathrm{mL}$ ) for $48 \mathrm{~h}$ and were used to test the cytotoxicity by MTT assay. OR, Oviductus Ranae; ORP, Oviductus Ranae protein; ORPH-pa, Oviductus Ranae protein hydrolysate prepared with papain; ORPH-tp, Oviductus Ranae protein hydrolysate prepared with trypsin; ORPH-pe, Oviductus Ranae protein hydrolysate prepared with pepsin; ORPH-np, Oviductus Ranae protein hydrolysate prepared with neutral protease; ORPHap, Oviductus Ranae protein hydrolysate prepared with alkaline protease. Control, untreated cells.

the concentration range of $10-500 \mu \mathrm{g} / \mathrm{mL}$ and did not result from neutral protease in ORPH-np (Figure 2(b)). However, this manner was not continued at the concentration of $1000 \mu \mathrm{g} / \mathrm{mL}$. Meanwhile, we also asked whether the effect of ORPH-np was in a time-dependent manner. The data shown in Figure 2(c) suggested that the phagocytic activity of macrophage was increased in a time-dependent manner in the time course of $0-48 \mathrm{~h}$, yet prolonged treatment $(72 \mathrm{~h})$ could not significantly increase the phagocytic activity of macrophage. These results showed that ORPH-np was able to regulate significantly phagocytosis of macrophage in a dose and time-dependent manner.

3.3. Effect of Protein Hydrolysate of Oviductus Ranae on NO Production. To further investigate whether ORPH-np activates macrophages, NO production of RAW 264.7 cells were determined by Griess assay. After cells were incubated with Oviductus Ranae protein or protein hydrolysates $(500 \mu \mathrm{g} / \mathrm{mL})$ for $24 \mathrm{~h}$, NO level of all experimental groups were significantly elevated compared to the control group. The highest induction was observed in the ORPH-np group, in which NO concentration was increased by $34.9 \%(P<$ 0.01) (Figure 3(a)). The stimulatory activity of ORPH-np also revealed a dose-dependent fashion in the concentration range of $10-500 \mu \mathrm{g} / \mathrm{mL}$ (stopped at $1000 \mu \mathrm{g} / \mathrm{mL}$.) and did not result from neutral protease in ORPH-np (Figure 3(b)). Similarly, we also examined whether there might be a timedependent manner in terms of the effect of ORPH-np. Again, as shown in Figure 3(c), NO production of macrophage was increased in a time-dependent manner from 0 to $48 \mathrm{~h}$, while no further change was seen with extended treatment (from 48-72 h). The above results demonstrated that ORPH-np regulated significantly phagocytosis and NO production of macrophage in a dose and time-dependent manner. From now on in the study, ORPH represents ORPH-np unless specified.

3.4. Effect of ORPH on the $m R N A$ and Protein Expression of $i N O S$. NO expressions are highly regulated by the synthesis of iNOS $[19,20]$. Therefore, the effect of ORPH on the expression levels of iNOS mRNA and protein in RAW 264.7 cells were investigated by RT-PCR and Western blot, and the results were showed in Figures 4(a) and 4(c). Both the expression levels of iNOS mRNA and protein increased remarkably after incubation with ORPH for $24 \mathrm{~h}(P<0.05)$, while $\beta$-actin remained unchanged (Figures $4(\mathrm{~b})$ and $4(\mathrm{~d})$ ). These results showed that ORPH did increase the mRNA and protein expression of iNOS in RAW 264.7 cells.

3.5. Effect of ORPH on Macrophage-Related Cytokine Production. To assess the effects of ORPH on TNF- $\alpha$, IL- $1 \beta$, and IL- 6 production by activated macrophages, RAW 264.7 cells were incubated in culture medium in the presence of $\mathrm{ORPH}$, and the quantities of these cytokines secreted into the culture supernatants were monitored by ELISA. AS shown as in Figure 5, a dose-dependent manner of TNF- $\alpha$, IL- $1 \beta$, and IL-6 production was observed again, when the cells were treated by a titration of ORPH $(10-500 \mu \mathrm{g} / \mathrm{mL})$. After cells were incubated with 100 or $500 \mu \mathrm{g} / \mathrm{mL}$ of $\mathrm{ORPH}$, marked increase was detected in TNF- $\alpha$, IL- $1 \beta$, and IL-6 secretion in the supernatant. $100 \mu \mathrm{g} / \mathrm{mL}$ of ORPH was able to increase the production of TNF- $\alpha$ by $37 \%$, IL- $1 \beta$ by $225 \%$, and IL- 6 by $75 \%$ whereas $500 \mu \mathrm{g} / \mathrm{mL}$ of ORPH enhanced production of TNF- $\alpha$ by $83 \%$, IL- $1 \beta$ by $290 \%$, and IL- 6 by $85 \%$ compared to the medium control (untreated group, $0 \mathrm{mg} / \mathrm{mL}$ ). However, this dose-dependent manner ceased at the concentration $1000 \mu \mathrm{g} / \mathrm{mL}$. These results indicated that ORPH exhibited significant immunostimulatory activity on macrophage related cytokine production.

3.6. Effect of Peptide with Different Molecular Weights on NO and TNF- $\alpha$ Production. The peptide length and molecular weight distribution of hydrolysates are considered to be closely related to their biological activities [21, 22]. In order to study the effect of molecular weight on the immunomodulatory activity, ORPH was separated into four different fractions by ultrafiltration. The effects of fractions with different molecular weights on $\mathrm{NO}$ and $\mathrm{TNF}-\alpha$ production of macrophages were investigated at $500 \mu \mathrm{g} / \mathrm{mL}$ level (Figures 6(a) and 6(b)). The $<3 \mathrm{kDa}$ and $3-5 \mathrm{kDa}$ fractions enhanced activity significantly, and $<3 \mathrm{kDa}$ peptide showed the highest stimulatory activity. The peptide of $<3 \mathrm{kDa}$ revealed stimulatory activity in a dose-dependent manner in the concentration range of $10-500 \mu \mathrm{g} / \mathrm{mL}$ and showed downregulatory trend at $1000 \mu \mathrm{g} / \mathrm{mL}$ (Figures 6(c) and 6(d)). The modulatory manner of the peptide with $<3 \mathrm{kDa}$ molecular weight was the same as ORPH. Several reports have shown that relatively low molecular weight peptide exhibited immunomodulating activity $[23,24]$. Based on these results, the peptide with $<3 \mathrm{kDa}$ molecular weight was the fraction responsible for the immunomodulatory activity. 


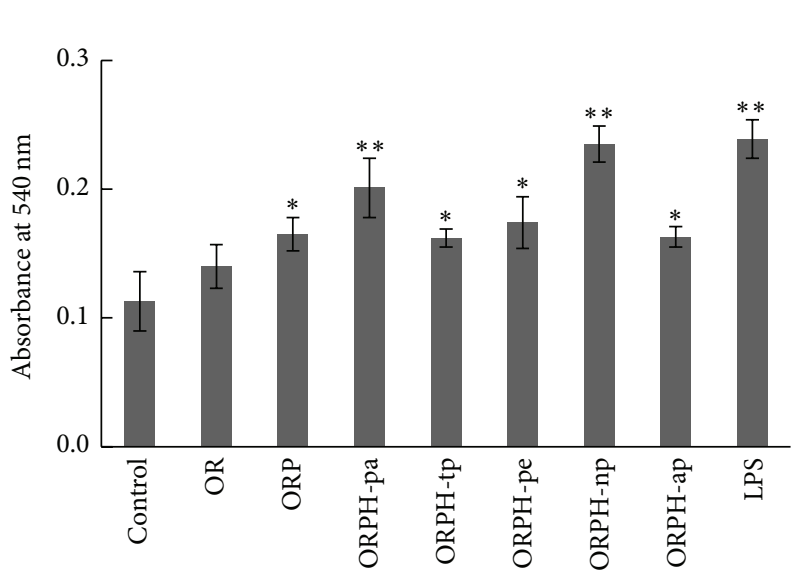

(a)

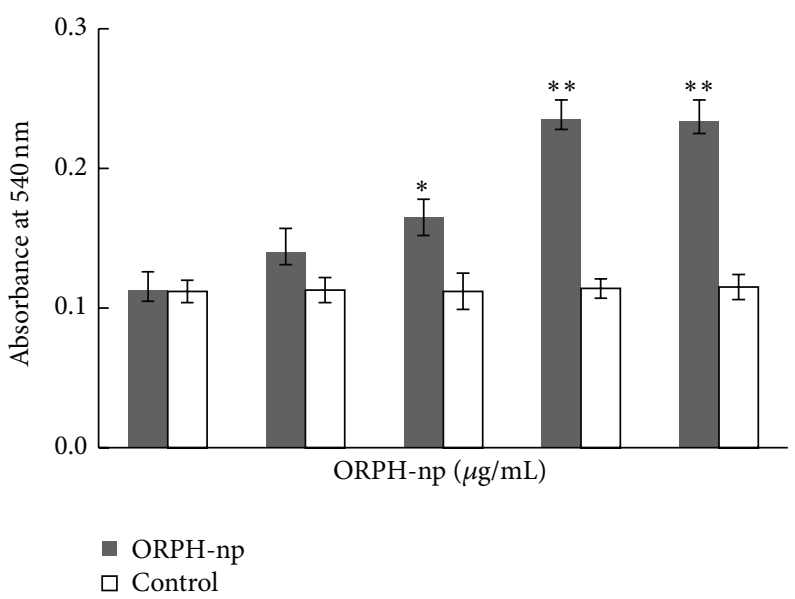

(b)

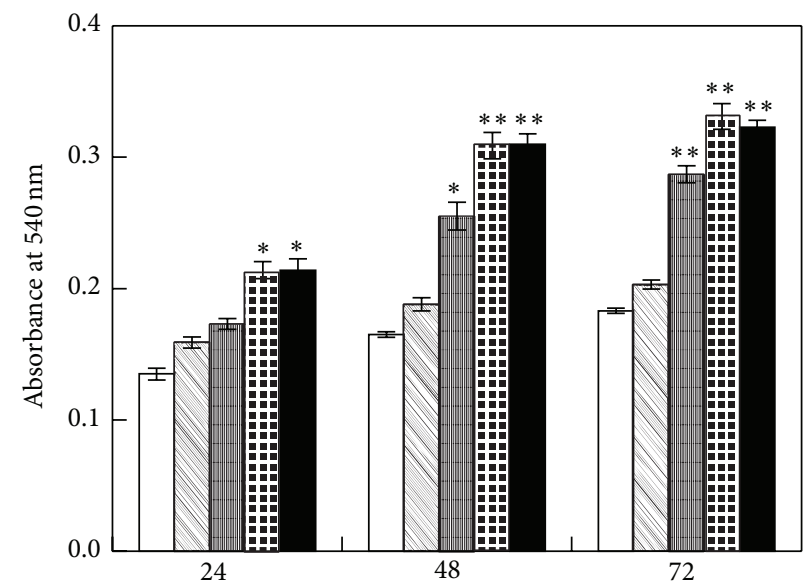

(h)

$$
\begin{aligned}
& \text { ㅁ } 0 \mu \mathrm{g} / \mathrm{mL} \\
& \Delta 10 \mu \mathrm{g} / \mathrm{mL} \\
& \text { II } 100 \mu \mathrm{g} / \mathrm{mL} \\
& \boxplus 500 \mu \mathrm{g} / \mathrm{mL} \\
& \text { [ } 1000 \mu \mathrm{g} / \mathrm{mL}
\end{aligned}
$$

(c)

FIGURE 2: Effect of protein hydrolysate of Oviductus Ranae on phagocytosis. (a) After treatment with test substances (500 $\mu \mathrm{g} / \mathrm{mL})$ or LPS $1 \mu \mathrm{g} / \mathrm{mL}$ for $48 \mathrm{~h}$, RAW 264.7 cells were used to test the phagocytosis by neutral red uptake assay. Control, untreated cells. (b) RAW 264.7 cells were pretreated with ORPH-np $(0,10,100,500$, and $1000 \mu \mathrm{g} / \mathrm{mL})$ for $48 \mathrm{~h}$ and were used to test the phagocytosis by neutral red uptake assay. Control cells were pretreated with the medium that contained same levels of neutral protease with ORPH-np, the neutral protease was processed by the same procedure with ORPH-np. (c) RAW 264.7 cells were pretreated with ORPH-np $(0,10,100,500$, and 1000 $\mu \mathrm{g} / \mathrm{mL})$ for 24,48 , and $72 \mathrm{~h}$ and were used to test the phagocytosis by neutral red uptake assay. Control, $0 \mu \mathrm{g} / \mathrm{mL}$. Results were expressed as means \pm S.D. of four separate experiments. Statistical significance test for comparison with untreated group was done by $t$-test. ${ }^{*} P<0.05$; ${ }^{* *} P<0.01$.

3.7. Effect of ORPH on the Activation of $N F-\kappa B$. Given that ORPH showed immunostimulatory activity on macrophage and NF- $\kappa \mathrm{B}$ is one of the most important transcription factors in regulation of macrophage activation, the content of nuclear $\mathrm{NF}-\kappa \mathrm{B}$ and cytoplasmic I $\kappa \mathrm{B}-\alpha$ was therefore detected by western blot. After incubating RAW 264.7 with $\mathrm{ORPH}(0,10$, 100 , and $500 \mu \mathrm{g} / \mathrm{mL})$ or LPS $(1 \mu \mathrm{g} / \mathrm{mL})$ for $24 \mathrm{~h}$, cytoplasmic and nuclear protein were extracted by the Cytoplasmic and Nuclear protein extract kit. The content of nuclear NF- $\kappa \mathrm{B}$ gradually increased after treated with ORPH (Figure $7(\mathrm{a})$ ), while that of cytoplasmic I $\kappa$ B $-\alpha$ displayed an opposite trend in a concentration-dependent manner (Figure 7(b)).
The results showed that the effect of ORPH on macrophage activities was likely to be mediated by the $\mathrm{I} \kappa \mathrm{B}-\mathrm{NF}-\kappa \mathrm{B}$ signaling pathway.

\section{Discussion}

To our knowledge, this is the first study that describes immunostimulatory activity of ORPH on macrophages in vitro. In this study, phagocytic assay by neutral red uptake illustrated that ORPH stimulated the phagocytosis of macrophages. The nitrite levels in the culture supernatant determined using Griess reagent revealed the elevation of NO 


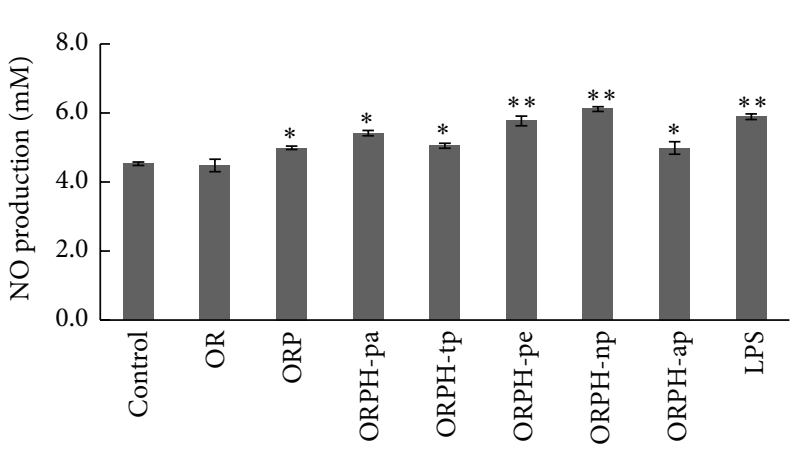

(a)

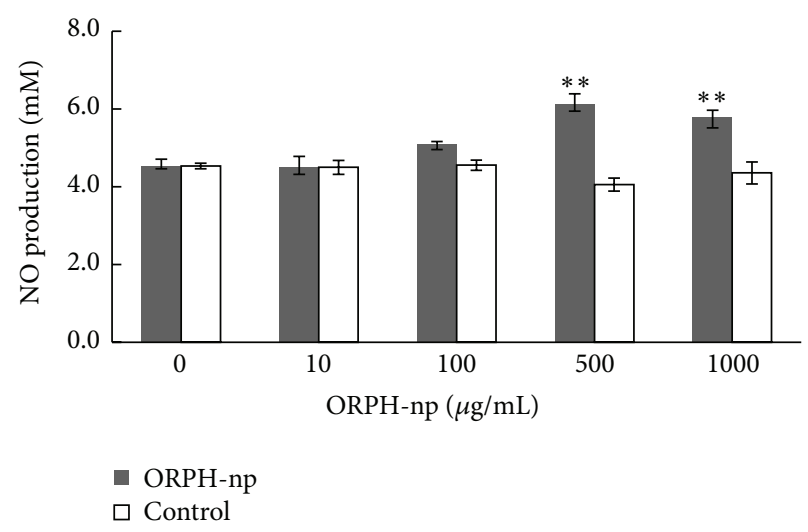

(b)

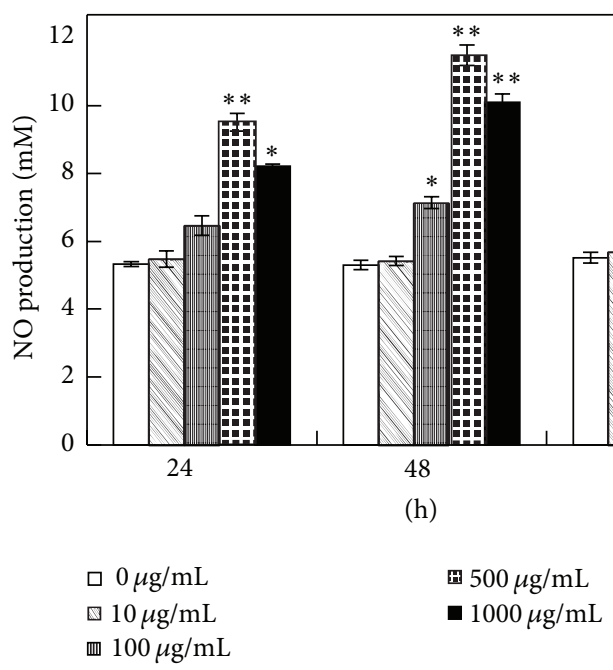

(c)

FIGURE 3: Effect of protein hydrolysate of Oviductus Ranae on NO production. (a) RAW 264.7 cells were pretreated with test substances $(500 \mu \mathrm{g} / \mathrm{mL})$ or LPS $(1 \mu \mathrm{g} / \mathrm{mL})$ for $48 \mathrm{~h}$. The supernatant nitrite levels were determined using Griess reagent. Control, untreated. (b) RAW 264.7 cells were pretreated with ORPH-np $(0,10,100,500$, and $1000 \mu \mathrm{g} / \mathrm{mL})$ for $48 \mathrm{~h}$, the supernatant nitrite levels were determined using Griess reagent. Control cells were pretreated with the medium that contained same levels of neutral protease with ORPH-np, the neutral protease was processed by the same procedure with ORPH. (c) RAW 264.7 cells were pretreated with ORPH-np (0, 10, 100, 500, and $1000 \mu \mathrm{g} / \mathrm{mL}$ ) for 24,48 , and $72 \mathrm{~h}$ and the supernatant nitrite levels were determined using Griess reagent. Control, $0 \mu \mathrm{g} / \mathrm{mL}$. Results were expressed as means \pm S.D. of four separate experiments. Statistical significance test for comparison with untreated group was done by $t$-test. ${ }^{*} P<0.05 ;{ }^{* *} P<0.01$.

production after treatment with ORPH. RT-PCR and Western blotting assay indicated that ORPH promoted the mRNA and protein expression of iNOS. ELISA assay showed the elevation of production of TNF- $\alpha$, IL- $1 \beta$, and IL- 6 after treatment with ORPH. Furthermore, the results of Western blotting demonstrated that NF- $\kappa \mathrm{B}$ levels in nucleuses increased after ORPH treatment. These findings suggested that effects of ORPH on macrophage activity might be due to the activation of NF- $\kappa \mathrm{B}$ pathway.

After phagocytic uptake, macrophages turn their role into antigen-presenting cells with expression of higher levels of costimulatory molecules and then mediate an interaction between T cells and macrophages [25]. In this study, phagocytosis assay of neutral red uptake internalization showed that ORPH significantly increased the phagocytosis of RAW
264.7 cells, which suggested that ORPH treatment might result in the initiation of immune reaction against foreign materials. Previous studies have shown that similar immunomodulating effects were found in enzymatic protein hydrolysates of whey [26, 27], fish [24, 28], and oyster [29]. In oyster, an increased phagocytic activity was detected by oyster protein hydrolysates treatment [29]. In pacific whiting (Merluccius productus), phagocytic activity of macrophages was enhanced following the fish protein concentrate (FPC) treatment suggesting that the FPC induced the release of cytokines able to activate immune cells for induction of the immune response [24]. In milk, the peptide from alpha-lactalbumin stimulated, in a dose-dependent manner, the binding of human senescent red blood cells to macrophage cells and phagocytosis by these cells [30]. In the present study, ORPH, 


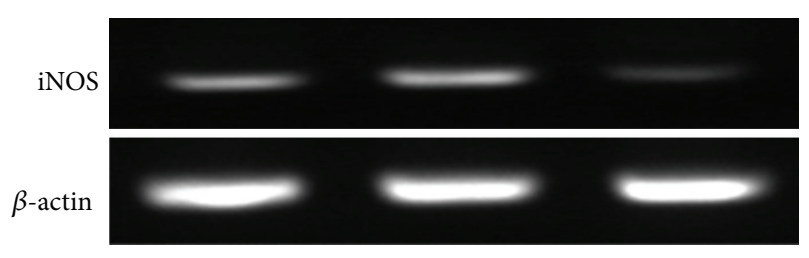

(a)

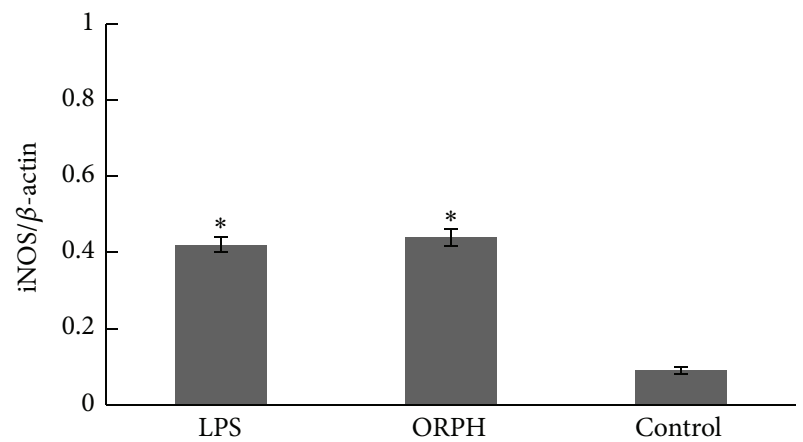

(b)

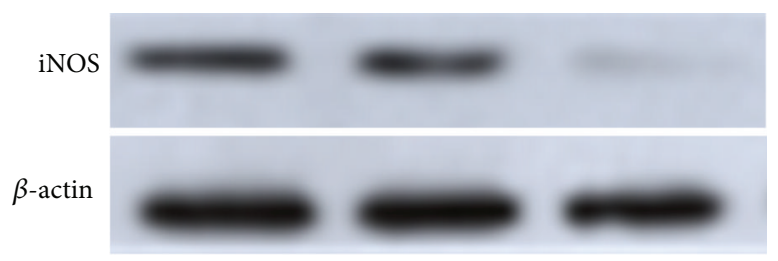

(c)

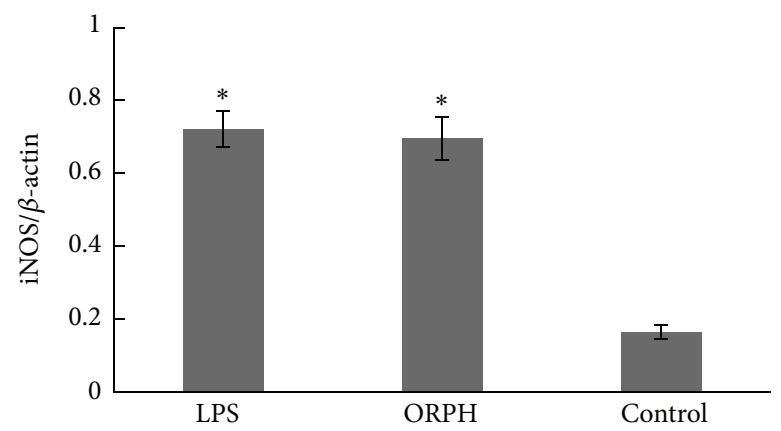

(d)

FIGURE 4: Effect of ORPH on expression of iNOS in RAW 264.7 cells. (a) Cells were incubated with ORPH (500 $\mu \mathrm{g} / \mathrm{mL})$ or LPS $(1 \mu \mathrm{g} / \mathrm{mL})$ for $24 \mathrm{~h}$. Total RNA was prepared and mRNA levels encoding iNOS was measured by RT-PCR. $\beta$-actin was used as an internal control. (b) Corresponding quantification data of iNOS mRNA expressional levels. (c) The protein level of iNOS in ORPH-stimulated RAW 264.7 cells was analyzed by Western blotting. (d) Corresponding quantification data of iNOS protein levels. ORPH, Oviductus Ranae protein hydrolysate prepared with neutral protease. Control, untreated. The results were stated in iNOS versus $\beta$-actin; data are expressed as mean \pm SD $(n=3)$. Statistical significance test for comparison with untreated group was done by $t$-test. ${ }^{*} P<0.05 ;{ }^{* *} P<0.01$.

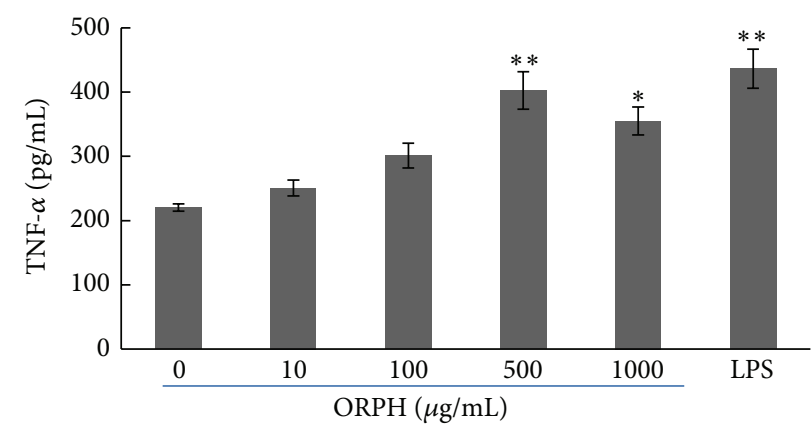

(a)

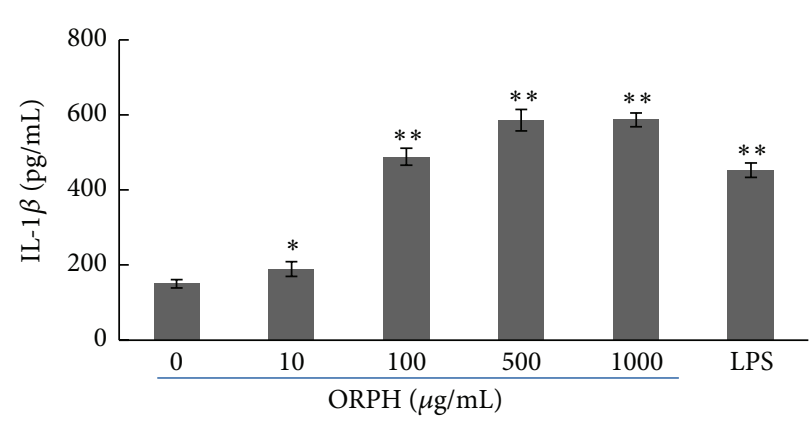

(b)

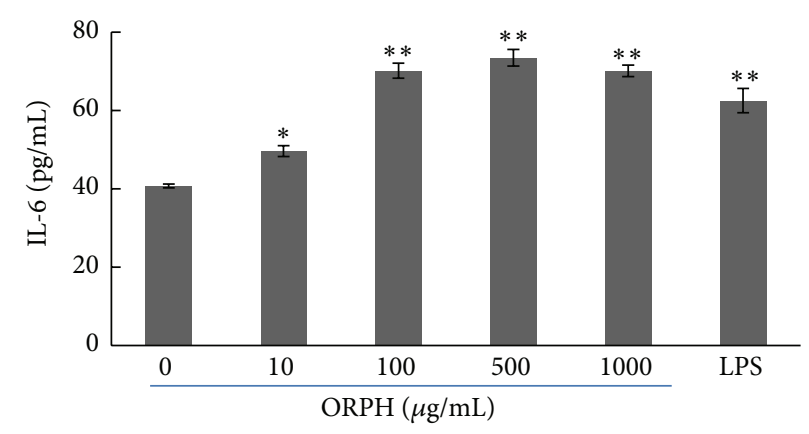

(c)

FIGURE 5: Effects of ORPH on macrophage-related cytokine production in macrophages. RAW 264.7 cells $\left(3 \times 10^{5}\right.$ cells/well) were cultured for $24 \mathrm{~h}$ in the presence of media with ORPH $(0-1000 \mu \mathrm{g} / \mathrm{mL})$ or LPS $(1 \mu \mathrm{g} / \mathrm{mL})$. The amounts of TNF- $\alpha$ (a), IL- $1 \beta$ (b), and IL-6 (c) released into the culture media were measured by immunoassays. ORPH, Oviductus Ranae protein hydrolysate prepared with neutral protease. Results were expressed as means \pm S.D. of four separate experiments. Statistical significance test for comparison with untreated group was done by $t$-test. ${ }^{*} P<0.05 ;{ }^{* *} P<0.01$. 


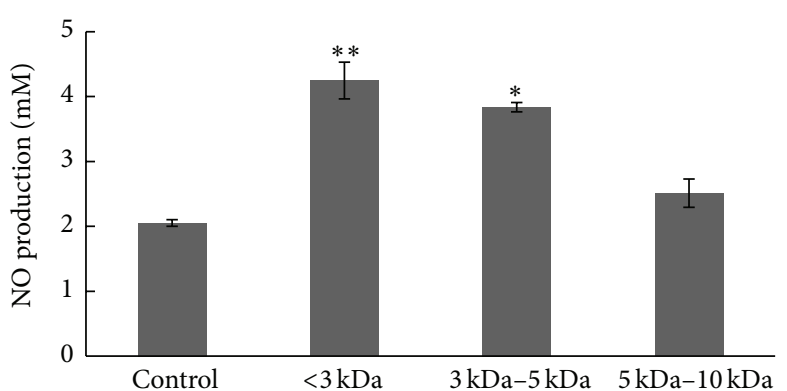

(a)

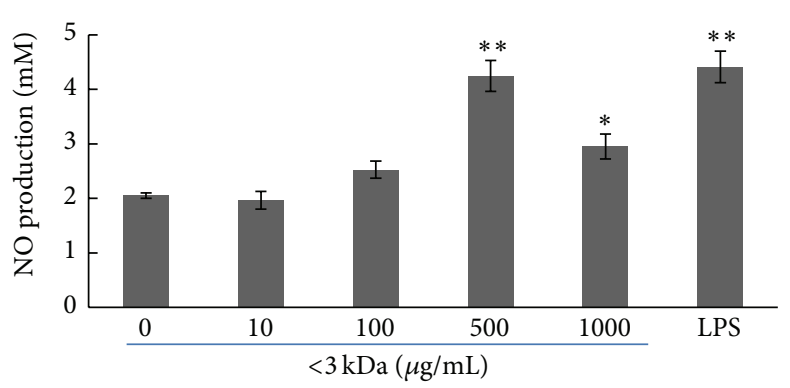

(c)

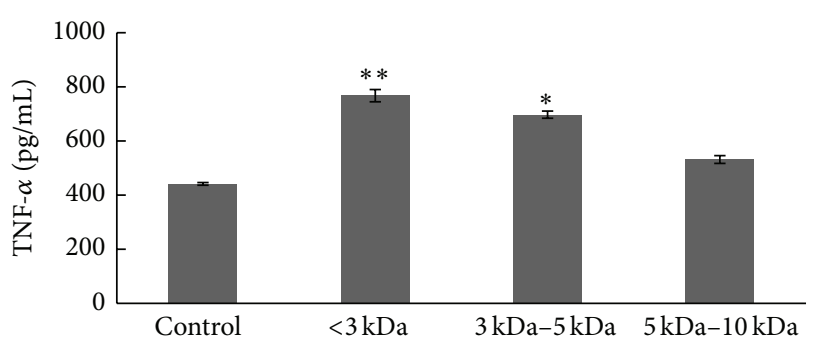

(b)

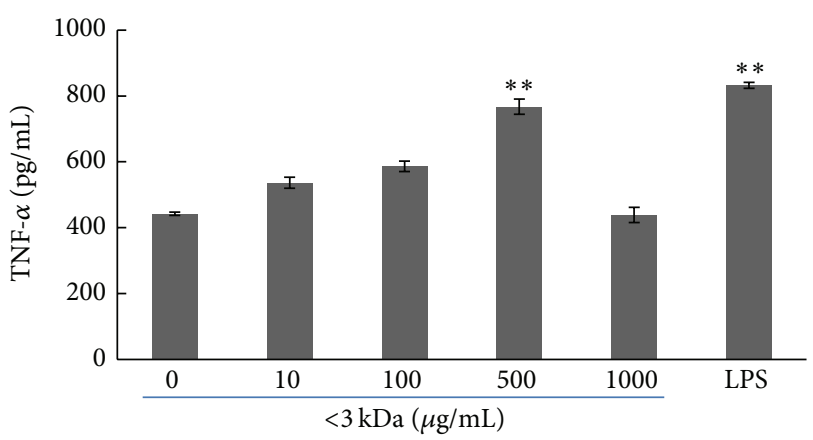

(d)

FIGURE 6: Effect of the peptide with different molecular weights on the NO and TNF- $\alpha$ production of RAW 264.7 cells. (a) and (b) cells were pretreated with or without test substances $(500 \mu \mathrm{g} / \mathrm{mL})$, respectively. The supernatant nitrite levels and TNF- $\alpha$ were determined using Griess reagent and ELISA kit, respectively. Control, $0 \mu \mathrm{g} / \mathrm{mL}$. (c) and (d) cells were cultured in the presence of media with the $<3 \mathrm{kDa}$ fraction $(0-1000 \mu \mathrm{g} / \mathrm{mL})$ or LPS $(1 \mu \mathrm{g} / \mathrm{mL})$. The amounts of NO and TNF- $\alpha$ in the supernatant were determined using Griess reagent and ELISA kit, respectively. ORPH, Oviductus Ranae protein hydrolysate prepared with neutral protease. Results were expressed as means \pm S.D. of four separate experiments. Statistical significance test for comparison with untreated group was done by $t$-test. ${ }^{*} P<0.05 ;{ }^{* *} P<0.01$.

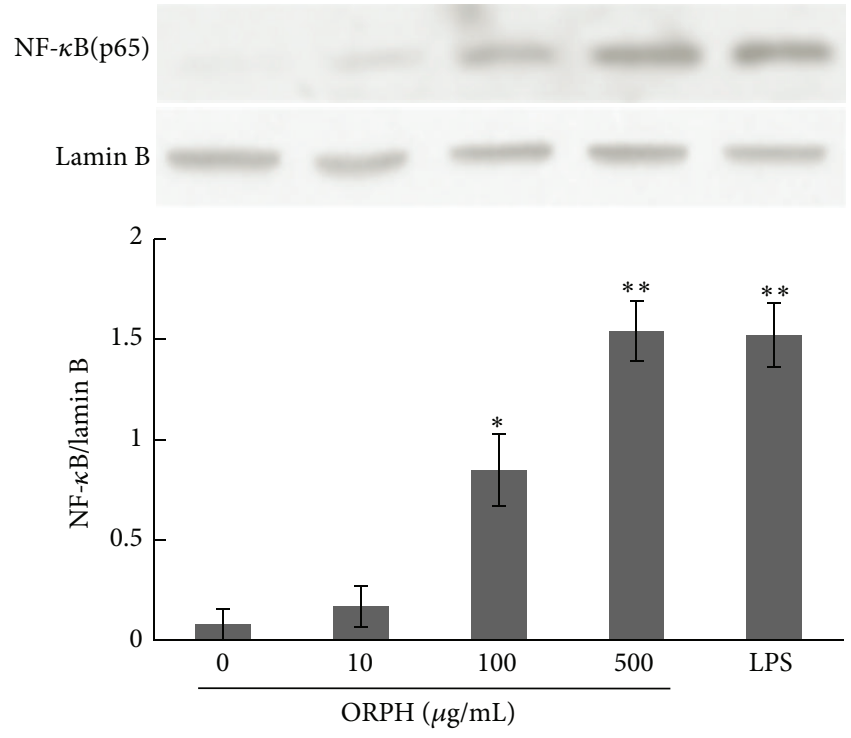

(a)
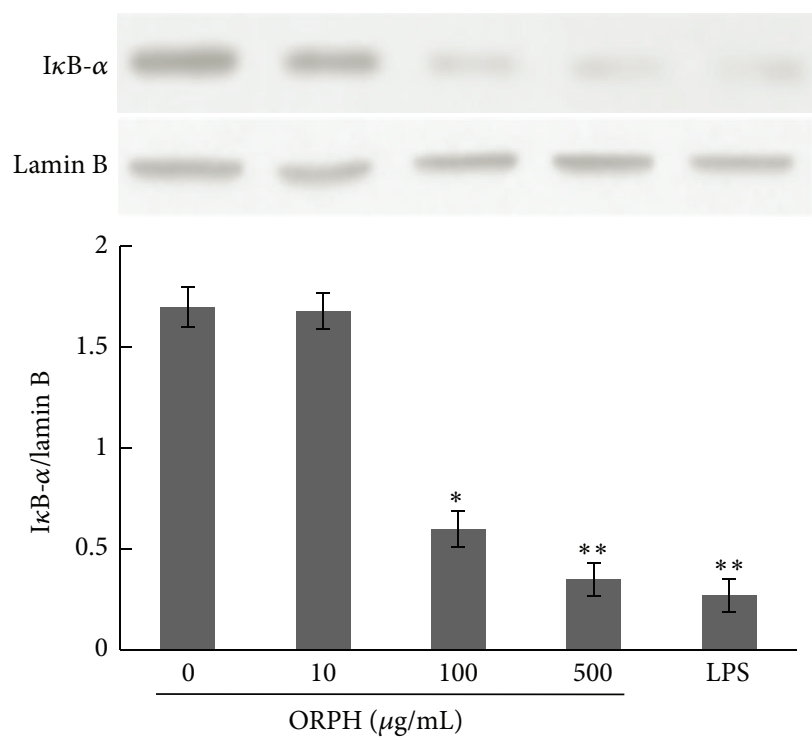

(b)

Figure 7: Effect of ORPH on nuclear NF- $\kappa$ B. (a) and cytoplasmic I $\kappa$ B- $\alpha$ (b) expression level by RAW 264.7 cells. Cells were cultured for $24 \mathrm{~h}$ in the presence of media with ORPH $(0-500 \mu \mathrm{g} / \mathrm{mL})$ or LPS $(1 \mu \mathrm{g} / \mathrm{mL})$. Western blotting was performed to detect the protein level of nuclear $\mathrm{NF}-\kappa \mathrm{B}$ and cytoplasmic I $\kappa \mathrm{B}-\alpha$. The levels of lamin B were measured as internal loading controls. The results were analyzed by iPP 6.0 software and stated in NF-jB versus Lamin B, data are expressed as mean \pm S.D. $(n=3)$. Statistical significance test for comparison with untreated group was done by $t$-test. ${ }^{*} P<0.05 ;{ }^{* *} P<0.01$. 
as another valuable source of biologically active peptides, was shown to closely relate to this similar immunostimulatory effect as well.

During the phagocytic process, activated macrophages produce NO. Since NO is related to the cytolytic function of macrophages against a variety of pathogens, increased NO synthesis can induce immunostimulatory activity in macrophages. When activated, macrophages also inhibit the invasion of microorganisms by releasing cytokines. NO is involved in diverse functions, including nerve growth, wound healing, and the immune response [9]. The present results showed that ORPH treatment increased the nitrite concentration in the supernatants in a dose and time dependent manner. To confirm the increase of NO production, the gene and protein expressions of iNOS were also analyzed by RT-PCR and western blotting in RAW 264.7 cells. Consistent with nitrite concentration data, the results collectively indicated that ORPH elevated the mRNA and protein level of iNOS. In the meantime, macrophage-related cytokines TNF- $\alpha$, IL- $1 \beta$, and IL- 6 were also investigated in this study to confirm that $\mathrm{ORPH}$ is an immunostimulator. Our results showed that the secretion levels of TNF- $\alpha$, IL-1 $\beta$, and IL- 6 were upregulated in ORPH-treated macrophages, suggesting the possible roles of macrophages in the antitumor activity upon ORPH treatment, as previously demonstrated for fermented milk [31] and fish protein hydrolysates [28]. Macrophages stimulated by ORPH produced TNF- $\alpha$ and IL-1 $\beta$, meaning that ORPH could induce the production of cytokines, resulting in the enhancement of TNF- $\alpha$ cytostaticity. IL- 6 is mainly produced by antigen-presenting cells, and has multiple biological activities in various cell types. In the development of cell-mediated immune responses, IL- 6 synergizes with IL- $1 \beta$ and promotes $\mathrm{T}$ cell proliferation, $\mathrm{T}$ helper cell differentiation, and development of T cell-mediated cytotoxicity by CD81 cells [32,33]. Therefore, ORPH stimulates macrophage-derived TNF- $\alpha$, IL$1 \beta$, and IL- 6 production, implying that ORPH might induce Th immune responses. The activation of macrophages through PRR receptors induces the expression of major histocompatibility complex (MHC) class II and costimulatory molecules such as CD40, CD80, and CD86, which are critical for $\mathrm{T}$ cell activation [34]. To further confirm that protein hydrolysate of Oviductus Ranae is effective for immunostimulation, future studies are needed to clarify the effect of protein hydrolysates on the expression of activation markers such as MHC class II, CD80, and CD86 induced by LPS in macrophages.

NF- $\kappa$ B plays a primary role in the transcriptional regulation of various genes such as macrophage-related cytokines [35]. When signals for the activation of NF- $\kappa \mathrm{B}$ are received, serine residues in $\mathrm{I} \kappa \mathrm{B}$ are phosphorylated and dissociated from NF- $\kappa \mathrm{B}$, which is then transferred to the nucleus as an activated transcription factor [36]. After the degradation of $\mathrm{I} \kappa \mathrm{B}$, the binding sites of $\mathrm{p} 50-\mathrm{p} 65$ dimer are then exposed to combine with the $\kappa \mathrm{B}$ motif. Then, the NF- $\kappa \mathrm{B}$ p 65 subunit would transfer from the cytoplasm to the nucleus with potent activity. In its active DNA-binding form, a large number of genes such as iNOS, IL-12p40, IL-1 $\beta$, TNF- $\alpha$, and IL-6 are regulated [17]. The present study revealed that ORPH increased the production of $\mathrm{NO}$ and the macrophage-related cytokines TNF- $\alpha$, IL-1 $\beta$, and IL-6. ORPH increased the level of NF- $\kappa \mathrm{B}$ activation in macrophages, which implicated that $\mathrm{ORPH}$ might stimulate the release of NF- $\kappa \mathrm{B}$ from $\mathrm{I} \kappa \mathrm{B}-$ $\alpha$ and transfer from cytoplasm to nucleus. Therefore, the present results raised the possibility that ORPH might induce macrophage activation through the NF- $\kappa$ B signaling pathway. It is well established that macrophages play pivotal roles in both innate and adaptive immune response to pathogens, including phagocytosis, antigen presentation, and cytokine secretion [37, 38]. However, large amounts of macrophagederived inflammatory mediators could also lead to the inflammatory responses. In particular, excessive production of TNF- $\alpha$, IL-1 $\beta$, and IL- 6 could aggravate inflammation diseases $[39,40]$. In addition, increased expression of iNOS and release of large amounts of $\mathrm{NO}$ also play a significant part in the pathogenesis of inflammatory and other diseases such as rheumatoid arthritis, chronic hepatitis, and pulmonary fibrosis $[41,42]$. The present results showed that extended the test ORPH concentration $1000 \mu \mathrm{g} / \mathrm{mL}$ and found that production of TNF- $\alpha$, IL-1 $\beta$, IL- 6 , and NO was upregulated in a dose-dependent manner in the concentration range of $10-500 \mu \mathrm{g} / \mathrm{mL}$, and the trend ceased at the concentration $1000 \mu \mathrm{g} / \mathrm{mL}$. These results suggested that proper regulation of these macrophage functions by immunomodulatory molecules such as ORPH could help a host to protect itself from various pathologic or cancerous attacks.

In conclusion, the present results demonstrated that ORPH was able to not only stimulate murine macrophage RAW 264.7 to secrete inflammatory cytokines, but also increase their phagocytic activity and NO production. Also, the increase in nuclear NF- $\kappa$ B level upon ORPH treatment was confirmed. These findings suggested that ORPH could induce macrophage activation, and this immunostimulatory activity was highly likely to be associated with the activation of NF- $\kappa \mathrm{B}$ signaling pathway.

\section{Conflict of Interests}

The authors report no conflict of interests.

\section{Authors' Contribution}

Meiyu Xu and Qiang Weng worked on experiments conceiving and design; Di Huang, Lubing Yang, Chenlu Wang, and Sihui Ma worked on experiments performing; Meiyu Xu and Xia Sheng performed data analysis; Di Huang and Meiyu Xu worked on the paper. All authors approved the final version.

\section{Acknowledgments}

This study is supported by a Grant-in-Aid from the National Natural Science Foundation of China (NSFC, no. J1103516) and Beijing Natural Science Foundation (8142029).

\section{References}

[1] M. Cutolo, "Macrophages as effectors of the immunoendocrinologic interactions in autoimmune rheumatic diseases," Annals of the New York Academy of Sciences, vol. 876, no. 1, pp. 32-42, 1999. 
[2] S. B. Gordon and R. C. Read, "Macrophage defences against respiratory tract infections," British Medical Bulletin, vol. 61, no. 1, pp. 45-61, 2002.

[3] S. B. Han, Y. D. Yoon, H. J. Ahn et al., "Toll-like receptormediated activation of B cells and macrophages by polysaccharide isolated from cell culture of Acanthopanax senticosus," International Immunopharmacology, vol. 3, no. 9, pp. 1301-1312, 2003.

[4] A. Tada, Y. Kaneiwa, J. Shoji, and S. Shibata, "Studies on the saponins of the root of Platycodon grandiflorum A. De Candolle. I. Isolation and the structure of platycodin-D," Chemical and Pharmaceutical Bulletin, vol. 23, no. 11, pp. 2965-2972, 1975.

[5] K. S. Kim, O. Ezaki, S. Ikemoto, and H. Itakura, "Effects of Platycodon grandiflorum feeding on serum and liver lipid concentrations in rats with diet-induced hyperlipidemia," Journal of Nutritional Science and Vitaminology, vol. 41, no. 4, pp. 485-491, 1995.

[6] S. Singh and A. K. Gupta, "Nitric oxide: role in tumour biology and iNOS/NO-based anticancer therapies," Cancer Chemotherapy and Pharmacology, vol. 67, no. 6, pp. 1211-1224, 2011.

[7] C. V. Rao, "Nitric oxide signaling in colon cancer chemoprevention," Mutation Research/Fundamental and Molecular Mechanisms of Mutagenesis, vol. 555, no. 1-2, pp. 107-119, 2004.

[8] F. R. Balkwill, M. S. Naylor, and S. Malik, "Tumour necrosis factor as an anticancer agent," European Journal of Cancer, vol. 26, no. 5, pp. 641-644, 1990.

[9] E. H. Han, J. H. Choi, Y. P. Hwang et al., "Immunostimulatory activity of aqueous extract isolated from Prunella vulgaris," Food and Chemical Toxicology, vol. 47, no. 1, pp. 62-69, 2009.

[10] Z. Zhang, B. Zhang, X. Nie, Q. Liu, F. Xie, and D. Shang, "Transcriptome analysis and identification of genes related to immune function in skin of the chinese brown frog," Zoological Science, vol. 26, no. 1, pp. 80-86, 2009.

[11] Y. Shen, Y. Liu, J. Ma et al., "Immunoreactivity of $c$-kit receptor protein during the prehibernation period in the oviduct of the Chinese brown frog, Rana chensinensis," The Journal of Veterinary Medical Science, vol. 74, no. 2, pp. 209-213, 2012.

[12] The State Pharmacopoeia Commission of the People's Republic of China, Pharmacopoeia of the People's Republic of China: Oviductus Ranae, Chemical Industry Press, Beijing, China, 2005.

[13] M. Zhang, Y. Li, B. Yao et al., "Transcriptome sequencing and de novo analysis for Oviductus Ranae of Rana chensinensis using illumina RNA-Seq technology," Journal of Genetics and Genomics, vol. 40, no. 3, pp. 137-140, 2013.

[14] Y. Xuegan, W. Yiquan, Z. Kaiya, and L. Zhongquan, "Authentication of oviductus ranae and its original animals using molecular marker," Biological and Pharmaceutical Bulletin, vol. 25, no. 8, pp. 1035-1039, 2002.

[15] F. Gao, H. Y. Zhang, K. Zhang et al., "A study on health functions of oviductus ranae," Chinese Journal Public Health, vol. 21, no. 1, pp. 9-10, 2005.

[16] X. Li, Y. Su, J. Sun, and Y. Yang, "Chicken embryo extracts enhance spleen lymphocyte and peritoneal macrophages function," Journal of Ethnopharmacology, vol. 144, no. 2, pp. 255-260, 2012.

[17] W. Chen, W. Zhang, W. Shen, and K. Wang, "Effects of the acid polysaccharide fraction isolated from a cultivated Cordyceps sinensis on macrophages in vitro," Cellular Immunology, vol. 262, no. 1, pp. 69-74, 2010.
[18] J. He, Y. Wang, L.-H. Xu, J. Qiao, D.-Y. Ouyang, and X.-H. He, "Cucurbitacin IIa induces caspase-3-dependent apoptosis and enhances autophagy in lipopolysaccharide-stimulated RAW 264.7 macrophages," International Immunopharmacology, vol. 16, no. 1, pp. 27-34, 2013.

[19] S. Koppula, W.-J. Kim, J. Jiang et al., “Carpesium macrocephalum attenuates lipopolysaccharide-induced inflammation in macrophages by regulating the NF- $\kappa \mathrm{B} / \mathrm{I} \kappa \mathrm{B}-\alpha$, Akt, and STAT signaling pathways," The American Journal of Chinese Medicine, vol. 41, no. 4, pp. 927-943, 2013.

[20] C. Bogdan, "Nitric oxide and the immune response," Nature Immunology, vol. 2, no. 10, pp. 907-916, 2001.

[21] J. Léonil, V. Gagnaire, D. Mollé, S. Pezennec, and S. Bouhallab, "Application of chromatography and mass spectrometry to the characterization of food proteins and derived peptides," Journal of Chromatography A, vol. 881, no. 1-2, pp. 1-21, 2000.

[22] D. Zhou, L. Qin, B. Zhu et al., "Optimisation of hydrolysis of purple sea urchin (Strongylocentrotus nudus) gonad by response surface methodology and evaluation of in vitro antioxidant activity of the hydrolysate," Journal of the Science of Food and Agriculture, vol. 92, no. 8, pp. 1694-1701, 2012.

[23] G. H. Werner, "Natural and synthetic peptides (other than neuropeptides) endowed with immunomodulating activities," Immunology Letters, vol. 16, no. 3-4, pp. 363-370, 1987.

[24] H. Hou, Y. Fan, B. Li, C. Xue, and G. Yu, "Preparation of immunomodulatory hydrolysates from Alaska pollock frame," Journal of the Science of Food and Agriculture, vol. 92, no. 15, pp. 30293038, 2012.

[25] K. Hoebe, E. M. Janssen, S. O. Kim et al., "Upregulation of costimulatory molecules induced by lipopolysaccharide and double-stranded RNA occurs by Trif-dependent and Trifindependent pathways," Nature Immunology, vol. 4, no. 12, pp. 1223-1229, 2003.

[26] S. C. Cheison, Z. Wang, and S.-Y. Xu, "Preparation of whey protein hydrolysates using a single- and two-stage enzymatic membrane reactor and their immunological and antioxidant properties: characterization by multivariate data analysis," Journal of Agricultural and Food Chemistry, vol. 55, no. 10, pp. 38963904, 2007.

[27] S. B. Kim, I. S. Seo, M. A. Khan et al., "Enzymatic hydrolysis of heated whey: iron-binding ability of peptides and antigenic protein fractions," Journal of Dairy Science, vol. 90, no. 9, pp. 4033-4042, 2007.

[28] J. Duarte, G. Vinderola, B. Ritz, G. Perdigón, and C. Matar, "Immunomodulating capacity of commercial fish protein hydrolysate for diet supplementation," Immunobiology, vol. 211, no. 5, pp. 341-350, 2006.

[29] Y.-K. Wang, H.-L. He, G.-F. Wang et al., “Oyster (Crassostrea gigas) hydrolysates produced on a plant scale have antitumor activity and immunostimulating effects in BALB/c mice," Marine Drugs, vol. 8, no. 2, pp. 255-268, 2010.

[30] L. Gattegno, D. Migliore-Samour, L. Saffar, and P. Jolles, "Enhancement of phagocytic activity of human monocyticmacrocytic cells by immunostimulating peptides from human casein," Immunology Letters, vol. 18, no. 1, pp. 27-31, 1988.

[31] G. Vinderola, G. Perdigón, J. Duarte, E. Farnworth, and C. Matar, "Effects of the oral administration of the exopolysaccharide produced by Lactobacillus kefiranofaciens on the gut mucosal immunity," Cytokine, vol. 36, no. 5-6, pp. 254-260, 2006.

[32] M. Okada, M. Kitahara, S. Kishimoto, T. Matsuda, T. Hirano, and T. Kishimoto, "IL-6/BSF-2 functions as a killer helper factor 
in the in vitro induction of cytotoxic T cells," The Journal of Immunology, vol. 141, no. 5, pp. 1543-1549, 1988.

[33] F. Houssiau and J. van Snick, "IL6 and T-cell response," Research in Immunology, vol. 143, no. 7, pp. 740-743, 1992.

[34] M. K. Crow, "Modification of accessory molecule signaling," Springer Seminars in Immunopathology, vol. 27, no. 4, pp. 409424, 2006.

[35] S. Ghosh, M. J. May, and E. B. Kopp, "NF-kappaB and rel proteins: Evolutionarily conserved mediators of immune responses," Annual Review of Immunology, vol. 16, no. 1, pp. 225260, 1998.

[36] S. Beinke and S. C. Ley, "Functions of NF- $\kappa$ B1 and NF- $\kappa$ B2 in immune cell biology," The Biochemical Journal, vol. 382, no. 2, pp. 393-409, 2004.

[37] L. Martinez-Pomares and S. Gordon, "Antigen presentation the macrophage way," Cell, vol. 131, no. 4, pp. 641-643, 2007.

[38] B. Acosta-Iborra, A. Elorza, I. M. Olazabal et al., "Macrophage oxygen sensing modulates antigen presentation and phagocytic functions involving IFN- $\gamma$ production through the HIF- $1 \alpha$ transcription factor," The Journal of Immunology, vol. 182, no. 5, pp. 3155-3164, 2009.

[39] E. F. Morand and M. Leech, "Macrophage migration inhibitory factor in rheumatoid arthritis," Frontiers in Bioscience, vol. 10, no. 1, pp. 12-22, 2005.

[40] B. Stuhlmuller, U. Ungethum, S. Scholze et al., "Identification of known and novel genes in activated monocytes from patients with rheumatoid arthritis," Arthritis and Rheumatism, vol. 43, no. 4, pp. 775-790, 2000.

[41] S. Moncada, R. M. J. Palmer, and E. A. Higgs, "Nitric oxide: physiology, pathophysiology, and pharmacology," Pharmacological Reviews, vol. 43, no. 2, pp. 109-142, 1991.

[42] S. Moncada and D. A. Higgs, "The L-arginine-nitric oxide pathway," The New England Journal of Medicine, vol. 329, no. 27, pp. 2002-2012, 1993. 


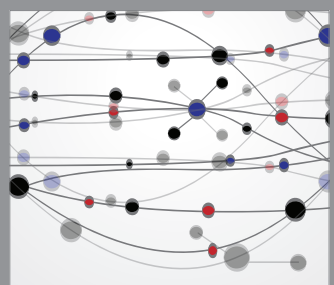

The Scientific World Journal
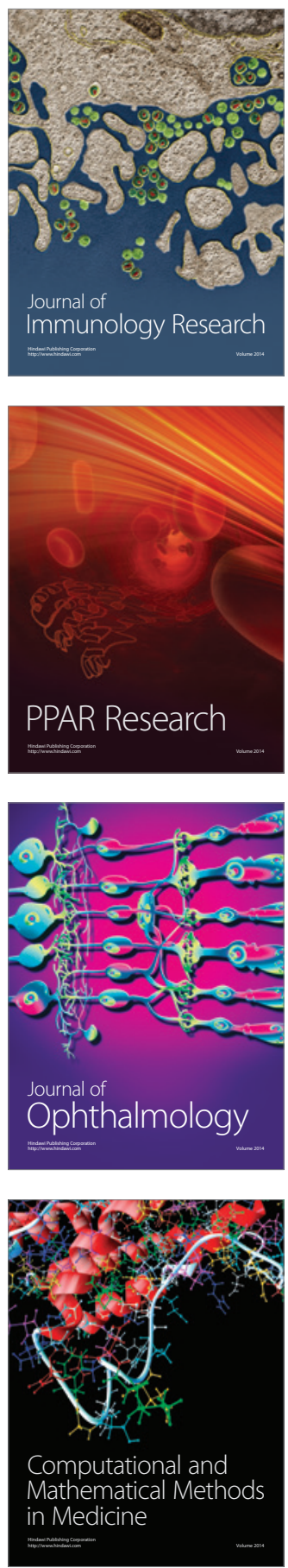

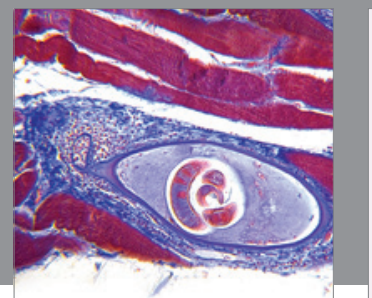

Gastroenterology

Research and Practice
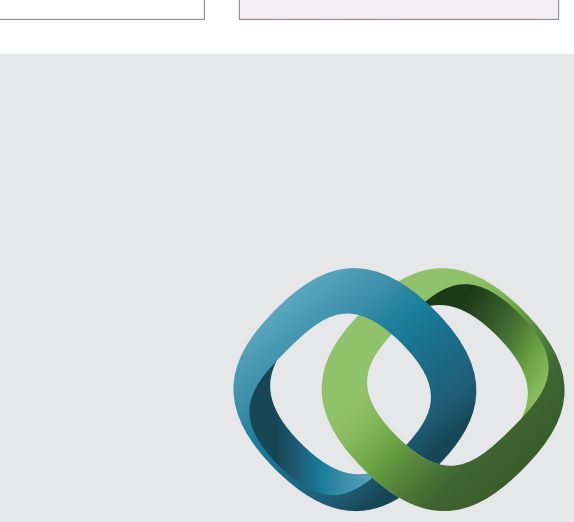

\section{Hindawi}

Submit your manuscripts at

http://www.hindawi.com
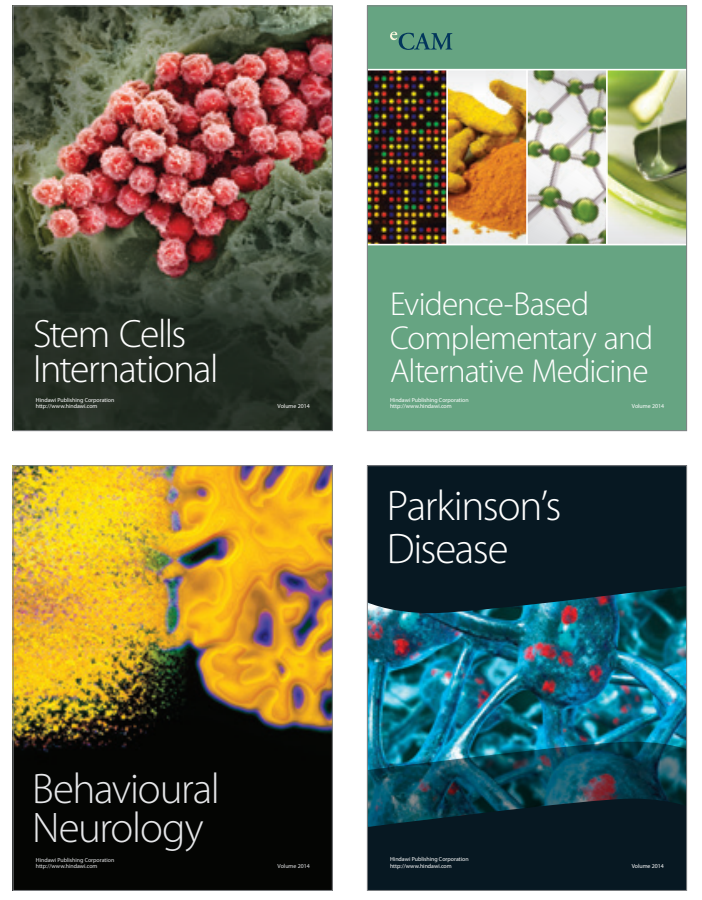
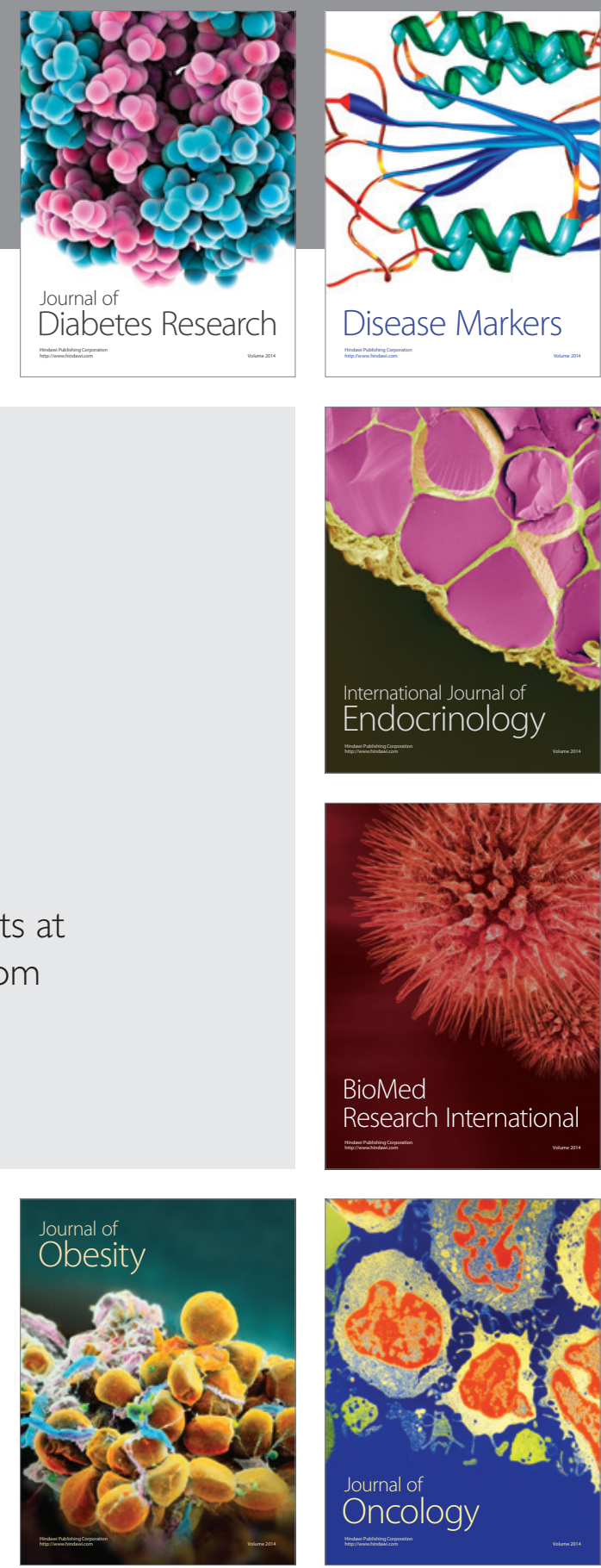

Disease Markers
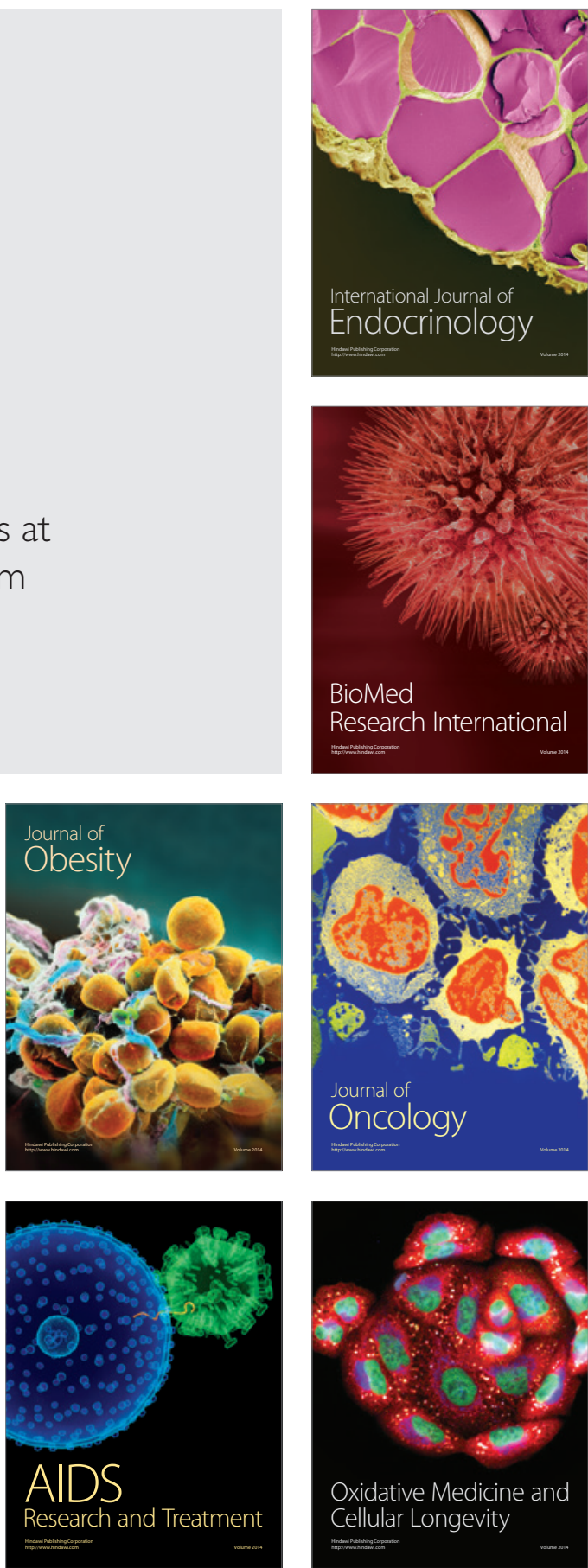